\title{
Clinical and radiographic evaluation of femoral shaft fractures in a pediatric population treated with titanium elastic nails
}

Titanyum elastik çivi ile tedavi edilmiş pediatrik popülasyondaki femur şaft kırıklarının klinik ve radyografik olarak değerlendirilmesi \\ ${ }^{1}$ Ankara City Hospital, Department of Orthopedics and Traumatology, Ankara, Turkey \\ ${ }^{2}$ Gülhane Training and Research Hospital, Department of Orthopedics and Traumatology, Ankara, Turkey
}

\begin{abstract}
Aim: The main goal of study is to evaluate the clinical, functional and radiographic results of titanium elastic nail (TEN), which is among the most preferred methods in the treatment of pediatric femoral shaft fractures.
\end{abstract}

Materials and Methods: In this study, 33 patients, the ages of from 4 to14 years and weighing less than $50 \mathrm{~kg}$, who were diagnosed with femoral shaft fractures between January 2018 and December 2019 and operated on with the TEN method in our clinic, were evaluated retrospectively. The demographic information of the patients, injury mechanism, fracture pattern, duration of surgery, radiographic union time, degree of residual deformity in the coronal and sagittal planes after union, nonunion rate, leg length discrepancy and postoperative weight-bearing times were examined.

Results: Femoral shaft fractures were seen 2.3 times more often in boys than in girls. Patients are often injured as a result of high-energy trauma such as traffic accidents and falls from a height. According to radiographic measurements, mean residual deformity of $3.23 \pm 2.46$ degrees in the coronal plane and $4.56 \pm 3.78$ degrees in the sagittal plane was measured and a mean discrepancy of $1.36 \pm 0.85 \mathrm{~cm}$ was found between the two legs. Radiographic union time was calculated as $10.41 \pm$ 3.55 weeks on average.

Conclusion: If applied with the right indication and the right technique, the TEN method is extremely important and successful in the treatment of femoral shaft fractures in pediatric patients younger than 15 years old and weighing less than $50 \mathrm{~kg}$.

Keywords: Femoral shaft fracture, Flynn criteria, radiographic measurement, titanium elastic nail.

\section{ÖZ}

Amaç: Bu çalışmadaki amaç çocuk femur şaft kırıklarının tedavisinde sık tercih edilen yöntemlerden biri olan titanyum elastik çivinin klinik, fonksiyonel ve radyografik sonuçlarını değerlendirmektir.

Gereç ve Yöntem: Çalışmada Ocak 2018-Aralık 2019 tarihlerinde femur şaft kırığı tanısı almış ve kliniğimizde titanyum elastik çivi yöntemiyle tedavi edilmiş, 4-14 yaş arası ve $50 \mathrm{~kg}$ altındaki 33 hasta geriye dönük olarak değerlendirildi. Hastaların demografik bilgileri, yaralanma mekanizması, kırık paterni, cerrahi süresi, radyografik kaynama süresi, kaynama sonrası koronal ve sagital planlardaki rezidü deformite derecesi, kaynamama oranı, bacak boyu eşitsizliği ve ameliyat sonrası yük verme süreleri incelendi.

\footnotetext{
Corresponding author: Ceyhun Çağlar

Ankara City Hospital, Department of Orthopedics and

Traumatology, Ankara, Turkey

E-mail: ceyhun.caglar@hotmail.com

Application date: 05.01.2021 
Bulgular: Femur şaft kırığı erkek çocuklarında kız çocuklarına göre 2,3 kat fazla görülmüştür. Hastalar genellikle trafik kazası ve yüksekten düşme gibi yüksek enerjili travmalar sonucu yaralanmıştır. Radyografik ölçümlere göre koronal planda ortalama 3,23 $\pm 2,46$ derece, sagital planda ise 4,56 \pm 3,78 derece rezidü deformite ölçülmüş olup, her iki bacak arasında ortalama 1,36 $\pm 0,85 \mathrm{~cm}$ eşitsizlik tespit edilmiştir. Radyografik kaynama süresi ise ortalama 10,41 \pm 3,55 hafta olarak hesaplanmıştır.

Sonuç: Doğru endikasyonla ve doğru teknikle uygulandığı takdirde titanyum elastik çivi tedavisi, 15 yaşından küçük ve 50 kg'dan daha az pediatrik popülasyondaki femur şaft kırıklarının tedavisinde son derece önemli ve başarılı bir yöntemdir.

Anahtar Sözcükler: Femur şaft kırığı, Flynn kriterleri, radyografik ölçüm, titanyum elastik çivi.

\section{INTRODUCTION}

Femoral shaft fractures, including supracondylar and per trochanteric fractures, account for approximately $1.6 \%$ of all fractures in the pediatric population (1). They usually occur after high-energy trauma such as a fall from a height or a traffic accident. These fractures are approximately 2.6 times more common in the male population and have a bimodal distribution between 2 and 12 years (1).

Although several classification systems have been described for femoral shaft fractures, few of them focus on pediatric patients (2). Regardless of the classification system used, femoral shaft fractures present challenges for orthopedic surgeons due to the internal stability of the fracture and the possibility of displacement (3). The iliopsoas muscle pulls the proximal part into flexion and external rotation, while the gluteus medius muscle pulls it into abduction $(4,5)$. In addition, the quadriceps, hamstrings and adductor muscles play a role in the displacement and shortening of the femoral shaft. The combination of all these results in compressive forces in the medial cortex and tensile forces in the lateral cortex (2).

In the past, most pediatric femoral shaft fractures were treated with skeletal traction and a hip spica cast $(6,7)$. However, the biggest handicap of this method was that the patient stayed in the hospital for a long time. The treatment method has been changing over time in parallel with the development of many alternative osteosynthesis methods such as external fixators, sub muscular plates and intramedullary nails. Thanks to these methods, the success of the treatment has increased, and the costs of hospitalization have decreased $(8,9)$.
In recent years, titanium elastic nail (TEN), which is frequently preferred in the treatment of femoral shaft fractures in the pediatric population, have been shown to be most appropriate $(10,11)$. TEN is the most recommended method in the treatment of displaced femoral shaft fractures in children between 6-15 years and weighing less than $50 \mathrm{~kg}$ (12). It is widely accepted in the treatment of femoral shaft fractures, especially in the transverse and short oblique pattern (13). TEN has advantages such as being minimally invasive and offering a short hospital stay, early mobilization and low complication rates (13). In addition, there is no risk of developing femoral head osteonecrosis.

The aim of this study is to evaluate femoral shaft fractures in a pediatric population treated with TEN, considering the clinical and radiographic results.

\section{MATERIALS and METHODS}

First of all, approval was obtained from the ethics committee of our hospital for this study (ID: E220-44 Date: 30/12/2020). Forty-five patients who were admitted to the emergency department of our hospital between January 2018 and December 2019 and were treated with TEN for a diagnosis of femoral shaft fracture were evaluated retrospectively. The study's inclusion criteria were as follows: patients between 4-14 years, weighing less than $50 \mathrm{~kg}$ and diagnosed with a closed femoral shaft fracture and treated with TEN. Exclusion criteria were as follows: patients younger than 4 years and older than 14 years, patients weighing over $50 \mathrm{~kg}$, those with open fractures or pathological fractures, those with additional fracture in the ipsilateral extremity, patients with congenital deformity and musculoskeletal dysplasia and those without regular clinical follow-up. Finally, the study 
continued with 33 patients who met these criteria. The demographic information of the patients, injury mechanism, fracture pattern, duration of surgery, radiographic union time, degree of residual deformity in the coronal and sagittal planes after union, nonunion rate, leg length discrepancy (LLD), and postoperative weightbearing times were recorded. In addition, patients were categorized according to the Flynn criteria. The parameters examined in the Flynn criteria are presented in (Table-1).

\section{Surgical technique}

All patients were operated on under general anesthesia. The fracture line was closed with traction and the reduction was confirmed by fluoroscopy. From the preoperative radiographs, the medullary canal diameter of the patients was measured; two TENs were selected to be $1 / 3$ of the diameter of the medullary canal (Figure-1). Then, with the help of fluoroscopy, the distal femur physis was determined and bilateral miniincision was made approximately $1 \mathrm{~cm}$ proximal to the physis line. After opening the entrance from the cortex to the medulla with the help of an awl, the TEN, placed laterally and medially, were advanced up to the greater trochanter and femoral neck, respectively and fracture fixation was completed. The operation was terminated after fracture alignment was confirmed by fluoroscopy.

\section{Rehabilitation}

All patients started knee and hip range of motion (ROM) exercises on the same day after surgery. All patients were discharged one day after surgery. According to the radiographic and clinical assessment, all patients were given partial weight-bearing between 4-6 weeks and full weight-bearing 8-10 weeks after the surgery.

\section{Radiographic assessment}

All patients underwent anteroposterior (AP) and lateral femoral radiography every two weeks for the first three months and monthly for three months to one year. Control radiographs were taken at regular intervals to determine residual deformity. Union criteria were determined radiographically with three of four cortex unions and absence of pain during weight-bearing.

Radiographic measurements were made in the clinic one year after surgery. The degree of residual deformity in the coronal and sagittal planes was calculated by measuring the angles between the alignments of the proximal and distal parts to the fracture line. The LLD was found by measuring the difference between the line passing through each acetabular tear drops and the lines passing through the lesser trochanters parallel to this line on pelvis AP radiography.

\section{Statistical analysis}

All statistical analyses were performed using SPSS 15.0 (SPSS Inc., Chicago, IL, USA). Data are presented as mean \pm standard deviation (SD) and minimum-maximum. The suitability of the data to normal distribution was evaluated with the Kolmogorov-Smirnov test and it was seen that all data were suitable for normal distribution.

\section{RESULTS}

The patients had a mean follow-up period of 23.3 months and their demographic information is shown in (Table-2). Femur shaft fractures were seen 2.3 times more often in boys than girls. There were patients in all age groups between 414 years. The weight and height measurements of the patients showed a wide distribution. When evaluated according to body mass index (BMI), underweight and normal weight children were affected more by femoral shaft fractures than overweight and obese children.

Injury mechanisms and fracture pattern distributions of the patients are presented respectively (Figure-2 and 3). It was observed that the patients were predominantly exposed to high-energy traumas such as traffic accidents and falls from a height. When the fracture pattern was evaluated radiographically, oblique fractures were the most common, followed by transverse, spiral, and butterfly fractures.

Table-3 shows the surgical and radiographic evaluation of the patients. The mean duration of surgery was less than one hour. When AP and lateral radiographs were evaluated, the union of three of the four cortices was considered as radiographic union and the mean union time was found to be $10.41 \pm 3.55$ weeks (Figure-4 and 6) . In addition, patients began to weight-bearing without pain approximately two weeks before the mean time of radiographic union. Although there was residual deformity in the coronal and sagittal planes after fracture union on the radiographs, 
the average values in both planes were calculated below $5^{\circ}$. Although an average lengthening of $1.36 \pm 0.85 \mathrm{~cm}$ was detected in the affected extremity after union compared to the healthy extremity, no clinical effects were observed in any patients. In addition, no rotational deformity was seen in any of patients with clinical signs, even though radiographic measurements were not performed.

When the results were evaluated according to the four parameters included in the Flynn criteria, 28 of 33 patients had excellent and 4 had satisfactory results, while only one patient had a poor result.
Infection occurred in one patient at the incision line in the early postoperative period. This patient was treated with wound debridement and antibiotic therapy without implant removal. In another patient, revision surgery was performed because of nonunion and loss of reduction in the fracture line. The TEN in the femur were removed, a thicker TEN was placed, and the fracture line was grafted with an autograft harvested from the iliac crest. In follow-up, complete radiographic union was achieved in this patient. There were no complications other than these.

Table-1. Functional results according to Flynn criteria.

\begin{tabular}{llll}
\hline & Excellent & Satisfactory & Poor \\
\hline LLD $(\mathrm{cm})$ & $<1$ & $<2$ & $>2$ \\
Malalignment $\left(^{\circ}\right)$ & $<5$ & $5-10$ & $>10$ \\
Pain & None & None & Present \\
Complication & None & Minor and resolved & Major and/or \\
& & & lasting morbidity \\
\hline
\end{tabular}

LLD: Leg length discrepancy, $\left({ }^{\circ}\right)$ : Angle

Table-2. Demographic characteristics of the patients.

\begin{tabular}{lll}
\hline Parameters & Mean \pm SD & Min-Max \\
\hline Gender $(\mathrm{n})$ & & \\
$\quad$ Male & 23 & \\
$\quad$ Female & 10 & $4-14$ \\
Age (year) & $8.23 \pm 3.38$ & $9-48$ \\
Weight $(\mathrm{kg})$ & $25.74 \pm 12.26$ & $88-162$ \\
Height $(\mathrm{cm})$ & $121.38 \pm 17.85$ & $11.24-32.45$ \\
Body mass index $\left(\mathrm{kg} / \mathrm{m}^{2}\right)$ & $17.25 \pm 5.04$ & \\
\hline
\end{tabular}

$\mathrm{n}$ : Number of patients, SD: Standard deviation, Min: Minimum, Max: Maximum

Table-3. Information on surgical and radiographic evaluation of patients.

\begin{tabular}{lll}
\hline Parameters & Mean \pm SD & Min-Max \\
\hline Surgery time (minute) & $51.45 \pm 18.92$ & $27-71$ \\
Radiographic union time (week) & $10.41 \pm 3.55$ & $7.4-19.7$ \\
Coronal plane residual deformity $\left(^{\circ}\right)$ & $3.23 \pm 2.46$ & $0-8$ \\
Sagittal plane residual deformity $\left(^{\circ}\right)$ & $4.56 \pm 3.78$ & $0-11$ \\
LLD $(\mathrm{cm})$ & $1.36 \pm 0.85$ & $0-2.8$ \\
Post-surgery weight bearing time (week) & $8.47 \pm 1.66$ & $5.8-11.3$ \\
\hline
\end{tabular}

$\left(^{\circ}\right)$ : Angle, LLD: Leg length discrepancy, SD: Standard deviation, Min: Minimum, Max: Maximum 


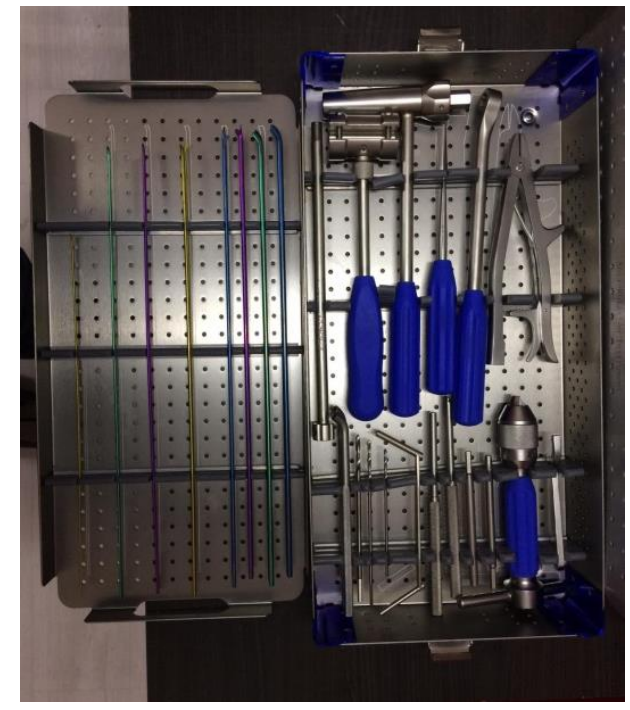

Figure-1. Titanium elastic nails used in the treatment of femoral shaft fractures in the pediatric population and surgical instruments used to apply these nails.

Injury mechanism of patients

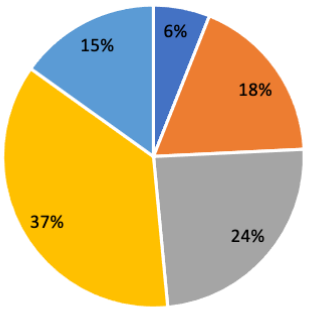

- Simple fall

- Fall from a height

- In-vehicle traffic accident

-n Non-vehicle traffic accident

m Bicycle accident

Figure-2. The distribution of the patients according to the injury mechanism is shown.

Fracture pattern of patients

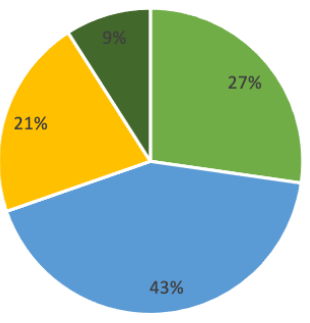

- Transverse

- Oblique

- Spiral

- Butterfly

Figure-3. The distribution of the patients according to the fracture pattern is shown.

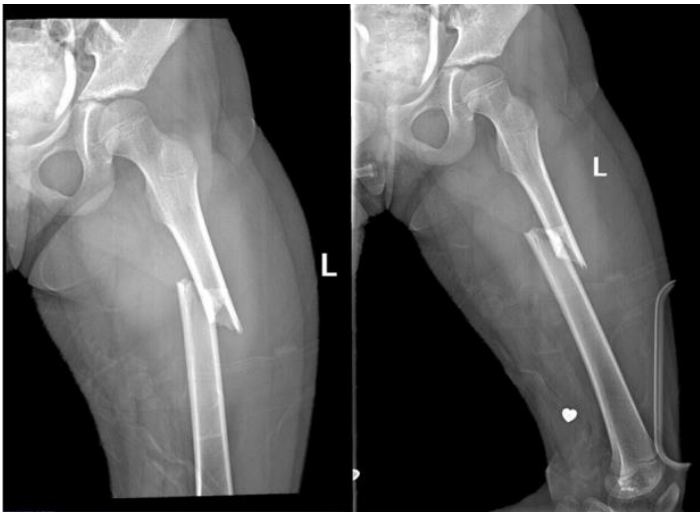

Figure-4. Fracture of the femoral shaft seen in the AP and lateral femoral radiographs of a 12year-old female patient who was brought to the emergency room after a non-vehicle traffic accident.

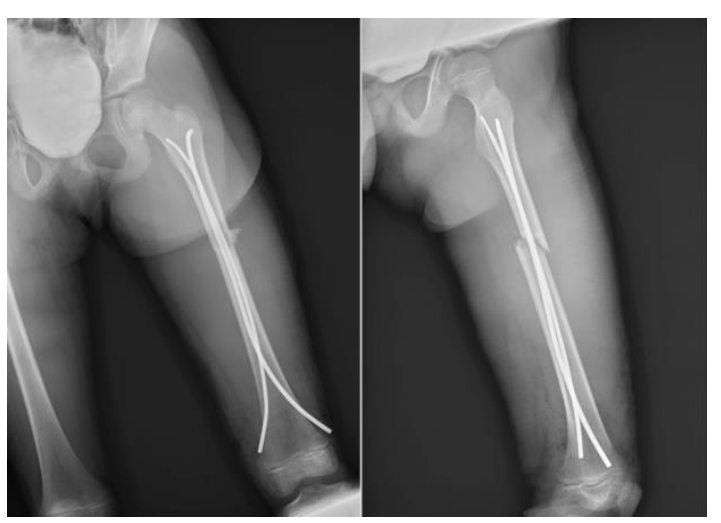

Figure-5. AP and lateral femur radiographs in the early postoperative period of the patient treated with titanium elastic nail.

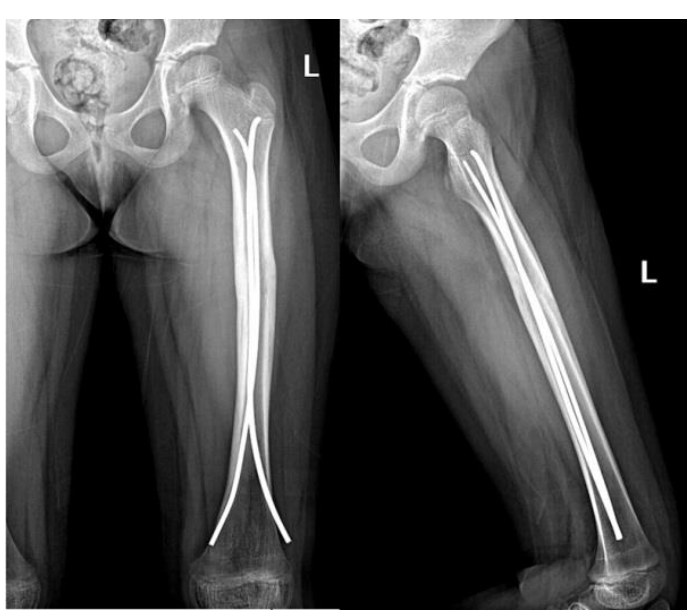

Figure-6. In the AP and lateral femur radiographs taken at the 10th week of the postoperative follow-up of the same patient, complete union was obtained in the fracture line. 


\section{DISCUSSION}

Surgical or conservative management of femoral shaft fractures in the pediatric population is still a topic of controversy among orthopedic surgeons. According to the literature, conservative treatment methods may cause union defect, joint stiffness, delayed functional recovery in older children, prolonged hospital stay and increased hospital costs (14). All of these complications increase the frequency of surgical treatment of femoral shaft fractures in the pediatric population.

In the surgical treatment of femoral shaft fractures in the pediatric population, TEN has surpassed other surgical techniques in recent years due to high rates of union, early mobilization, limited surgical dissection and short hospital stay (15). Clinical and biomechanical studies have shown that the TEN method applied for lower extremity fractures in children and adolescents is reliable, reproducible, effective in fracture union, minimally invasive and biomechanically stable $(16,17)$. Forty-two patients with femoral shaft fractures treated with TEN were followed and all fractures healed in an average of 88 days after the injury (18). According to another study, 31 femoral shaft fractures treated with TEN were followed regularly and all fractures healed within 12 weeks without delayed union (19). In our study, radiographic union was obtained in all patients except one in a mean of 10.41 weeks. Radiographic improvement was obtained after revision surgery in the sole case of nonunion and we think that the problem was insufficient fixation after the first surgery.

TEN is generally recommended for the treatment of displaced femoral shaft fractures in patients between 6-15 years and weighing less than $50 \mathrm{~kg}$ (20). In one study, a high complication rate was reported in children over $50 \mathrm{~kg}$ with displaced femoral shaft fractures treated with TEN (21). In another study, complications such as LLD and malunion were detected in children over $50 \mathrm{~kg}$ with displaced femur shaft fractures after the TEN technique (22). In our study, due to the complications that could have occurred, we did not apply TEN for any patient over the age of 14 or heavier than $49 \mathrm{~kg}$ and we thus remained within the recommended limits.

There are alternative techniques to TEN in the surgical treatment of femoral shaft fractures in the pediatric population. In one study, 51 patients who were diagnosed with femoral shaft fractures and treated with TEN or locking compression plate were evaluated retrospectively and although equal results were obtained with both treatments, shorter operation time, less blood loss during surgery and shorter hospital stay were observed in these patients (13). In another study, it was reported that open reduction and plate fixation should be avoided in the treatment of pediatric femoral shaft fractures because excessive soft tissue dissection leads to displacement of the fracture line (3). In another study, 38 patients with femoral shaft fractures treated with TEN or bridge plating were evaluated; no significant difference was found between the two groups functionally or radiologically and acceptable results were obtained (23). In a similar study, 65 patients treated with TEN or sub muscular plating were retrospectively examined and although functionally and radiologically equivalent results were found, the duration of surgery, blood loss during surgery and hospital costs were significantly higher in the group treated with sub muscular plating (24). In our study, although we did not have a control group, we obtained satisfactory radiographic and functional results in 33 patients treated with TEN. Surgery times and radiographic union times were similar to those of previous studies. In addition, we obtained excellent or satisfactory results in $32(97 \%)$ patients according to the Flynn criteria.

LLD or residual angulation seen in the coronal or sagittal plane after radiographic healing in femoral shaft fractures in the pediatric population is an important problem. Angulation of $>10^{\circ}$ in the coronal plane, $>15^{\circ}$ angulation in the sagittal plane, and LLD greater than $2.5 \mathrm{~cm}$ may lead to poor clinical results (22). In a previous study, 24 patients who were treated for femoral shaft fracture were evaluated retrospectively and although varus deformity developed in four patients and procurvatum deformity was seen in one patient after radiographic healing, no clinical effect was determined because all deformities were $<10^{\circ}(25)$. In a similar study, means of $5^{\circ}$ varus and $5.4^{\circ}$ procurvatum deformity were observed after radiographic recovery in the patient group treated with TEN, but these results did not reflect negatively on the clinical results 
(23). In another study, 30 patients treated by the TEN method were evaluated retrospectively, and although an average of $3.2^{\circ}$ varus, $0.53^{\circ}$ valgus, and $2.4^{\circ}$ procurvatum deformities and a mean of $0.71 \mathrm{~cm}$ LLD were detected, none of the patients were functionally affected (26). In our study, a residual deformity of less than $5^{\circ}$ in the coronal and sagittal planes and an average LLD of 1.36 $\mathrm{cm}$ were obtained, but the patients did not experience functional loss. We think that obtaining good radiographic results affects the future clinical and functional results.

Our study has some limitations: it is a retrospective study and patients with femoral shaft fractures who were treated only with TEN were evaluated and we did not have a control group. Although all radiographic measurements were made by the same observer, there may have been a margin of error since the measurements were made manually. While evaluating the patients according to the Flynn criteria, sufficiently objective data may not have been obtained because some criteria are based on patient statements. Finally, although we have a follow-up period of approximately two years, longer follow-up is needed in these patients as the growth continues.

\section{CONCLUSION}

The TEN method applied in the treatment of femoral shaft fractures in children younger than 15 years and weighing less than $50 \mathrm{~kg}$ is extremely successful. Its main advantages are its short duration of surgery and hospitalization, being an easily applicable and minimally invasive technique and extremely satisfactory functional and radiographic results. More patients and longer follow-up periods are needed to better evaluate the results of the TEN method.

Conflicts of Interest: The authors declare that they have no conflict of interest.

\section{References}

1. Loder RT, O'Donnell PW, Feinberg JR. Epidemiology and mechanisms of femur fractures in children. J Pediatr Orthop 2006; 26 (5): 561-6.

2. Loizou CL, McNamara I, Ahmed K, Pryor GA, Parker MJ. Classification of subtrochanteric femoral fractures. Injury 2010; 41 (7): 739-45.

3. Jarvis J, Davidson D, Letts M. Management of subtrochanteric fractures in skeletally immature adolescents. J Trauma 2006; 60 (3): 613-9.

4. Pombo MW, Shilt JS. The definition and treatment of pediatric subtrochanteric femur fractures with titanium elastic nails. J Pediatr Orthop 2006; 26 (3): 364-70.

5. Ireland DC, Fisher RL. Subtrochanteric fractures of the femur in children. Clin Orthop Relat Res 1975; (110): 157-66.

6. Catena N, Sénès FM, Riganti S, Boero S. Diaphyseal femoral fractures below the age of six years: results of plaster application and long term followup. Indian J Orthop 2014; 48 (1): 30-4.

7. Flynn JM, Schwend RM, Flynn JM, Schwend RM. Management of pediatric femoral shaft fractures. J Am Acad Orthop Surg 2004; 12 (5): 347-59.

8. Kosuge D, Barry M. Changing trends in the management of children's fractures. Bone Joint J 2015;97-B (4): 442-8.

9. Flynn JM, Luedtke LM, Ganley TJ, Dawson J, Davidson RS, Dormans JP, et al. Comparison of titanium elastic nails with traction and a spica cast to treat femoral fractures in children. J Bone Joint Surg Am 2004; 86 (4): 770-7.

10. Bopst L, Reinberg O, Lutz N. Femur fracture in preschool children: experience with flexible intramedullary nailing in 72 children. J Pediatr Orthop 2007; 27 (3): 299-303.

11. Winquist RA, Hansen Jr ST, Clawson DK. Closed intramedullary nailing of femoral fractures. A report of five hundred and twenty cases. J Bone Joint Surg Am 1984; 66 (4): 529-39. 
12. Andreacchio A, Alberghina F, Marengo L, Canavese F. Pediatric tibia and femur fractures in patients weighing more than $50 \mathrm{~kg}(110 \mathrm{lb})$ : mini-review on current treatment options and outcome. Musculoskelet Surg 2019; 103 (1): 23-30.

13. Luo Y, Wang L, Zhao LH, Wang YC, Chen MJ, Wang S, et al. Elastic Stable Titanium Flexible Intramedullary Nails Versus Plates in Treating Low Grade Comminuted Femur Shaft Fractures in Children. Orthop Surg 2019; 11 (4): 664-70.

14. Memeo A, Panuccio E, D'Amato RD, Colombo M, Boero S, Andreacchio A, et al. Retrospective, multicenter evaluation of complications in the treatment of diaphyseal femur fractures in pediatric patients. Injury 2019;50 Suppl 4: S60-3.

15. Ho CA, Skaggs DL, Tang CW, Kay RM. Use of flexible intramedullary nails in pediatric femur fractures. J Pediatr Orthop 2006; 26 (4): 497-504.

16. Han B, Wang Z, Li Y, Xu Y, Cai H. Risk factors for refracture of the forearm in children treated with elastic stable intramedullary nailing. Int Orthop 2019; 43 (9): 2093-7.

17. Kamara A, Ji X, Liu T, Zhan Y, Li J, Wang E. A comparative biomechanical study on different fixation techniques in the management of transverse metaphyseal-diaphyseal junction fractures of the distal humerus in children. Int Orthop 2019; 43 (2): 411-6.

18. Buechsenschuetz KE, Mehlman CT, Shaw KJ, Crawford AH, Immerman EB. Femoral shaft fracture in children: traction and casting versus casting versus elastic stable intramedullary nailing. J Trauma 2002; 53 (5): 914-21.

19. Oh CW, Park BC, Kim PT, Kyung HS, Kim SJ, Ihn JC. Retrograde flexible intramedullary nailing in children's femoral fractures. Int Orthop 2002; 26 (1): 52-5.

20. Kocher MS, Sink EL, Blasier RD, Luhmann SJ, Mehlman CT, Scher DM, et al. Treatment of pediatric diaphyseal femur fractures. J Am Acad Orthop Surg 2009; 17 (11): 718-25.

21. Canavese F, Marengo L, Andreacchio A, Mansour M, Paonessa M, Rousset M, et al. Complications of elastic stable intramedullary nailing of femoral shaft fractures in children weighing fifty kilograms (one hundred and ten pounds) and more. Int Orthop 2016; 40 (12): 2627-34.

22. Sagan ML, Datta JC, Olney BW, Lansford TJ, Mclff TE. Residual deformity after treatment of pediatric femur fractures with flexible titanium nails. J Pediatr Orthop 2010; 30 (7): 638-43.

23. Dey S, Mishra K, Nagda TV, Dhamele J, Rathod C, Dey D. Titanium Elastic Nailing with Temporary External Fixator versus Bridge Plating in Comminuted Pediatric Femoral Shaft Fractures: A Comparative Study. Indian J Orthop 2018; 52 (5): 507-12.

24. Allen JD, Murr K, Albitar F, Jacobs C, Moghadamian ES, Muchow R. Titanium Elastic Nailing has Superior Value to Plate Fixation of Midshaft Femur Fractures in Children 5 to 11 Years. J Pediatr Orthop $2018 ; 38$ (3): e111-7.

25. Alberghina F, Andreacchio A, Cravino M, Paonessa M, Canavese F. Extra-articular proximal femur fractures in children and adolescents treated by elastic stable intramedullary nailing. Int Orthop 2019; 43 (12): $2849-56$.

26. Kayaokay K, Aktuglu K. Titanium elastic nailing in pediatric femoral diaphyseal fractures in the age group of 6 15 years mid-term and long-term outcomes. Pak J Med Sci 2018; 34 (6): 1529-33. 